\title{
Critical analysis of etiological factors of ajirna (indigestion)
}

\begin{abstract}
Ayurveda is the age old traditional medical science deals with the management and prevention of diseases. Most of the diseases arise due to hypo functioning of Agni (biodigestive power) and it is the root cause for the development of many diseases. Ayu (long life), Bala (strength) and Varna (complexion) etc dependent on status of Agni. Agni present in the Jathara (Stomach and Intestine) which digest and metabolize the food and assist in growth of body hence it is termed as Bhagawan Ishvara- almighty God- himself. All the diseases arise as a result of less, excessive and irregular digestion of food known as Mandagni, Tikshnagni or Vishamagni respectively. Agni may get disturbed by erratic lifestyle and abnormal dietetic regimen. Disturbed functions of Agni causes indigestion of food is termed as Ajirna (indigestion). Ajirna is the most important source of production of Ama and favours genesis diseases. Avoidance of the etiological factor is the initial action in the management. Inappropriate life style, unreliable seasonal regimen adherence, mental disturbance and stress may contribute in the progress of Ajirna condition.
\end{abstract}

Keywords: agni, ajirna, ama, amajirna, vidagdhajirna, vistabdhajirna
Volume 5 Issue I - 2017

\author{
Neera Saini,' Pradeep Kumar Pal, ${ }^{2}$ P.S Byadgi ${ }^{3}$ \\ 'Department of Vikriti Vigyan, Faculty of Ayurveda, Institute of \\ Medical Sciences, India \\ ${ }^{2}$ Department of Rachana Sharira, Faculty of Ayurveda, Institute \\ of Medical Sciences, India \\ ${ }^{3}$ Department of Vikriti Vigyan, Faculty of Ayurveda, Banaras \\ Hindu University, India
}

Correspondence: P.S. Byadgi, Associate Professor, Department of Vikriti Vigyan, Faculty of Ayurveda, Institute of Medical Sciences, Banaras Hindu University, Varanasi, India, Email psbyadgi@gmail.com

Received: April 22, 2016 | Published: January 03, 2017

\section{Introduction}

Ajirna is the state of incomplete process of digestion of ingested food. The main reason for indigestion is the deranged functions of Agni. Incomplete digestion and metabolism due to disturbed digestive fire leads to formation of under processed state of food termed as ajirna. ${ }^{1}$ Persons who eat food in excessive quantities recklessly like cattle become prone for the development of ajirna ${ }^{2}$ which may lead development of many diseases.

\section{Concept of agni}

The term Agni, in common language, means fire. However, in the context of functioning of living organism, which maintains its integrity and performs its vital activities, by converting-in Pakadi Karmas or biophysical and biochemical processes - the foods consumed in various ways- licked, masticated, drunk etc., not only into its various structure and functional constituents but also to provide the energy, necessary for proceeding with its innumerable vital activities. In these sequences, the term Agni comprehends various factors which participate in and direct the course of digestion and metabolism, in a living organism. Hence it is termed as bio digestive fire. ${ }^{3-5}$ Vata (Prana, Apana, Samana and Udana) augments the digestive fire. Power of Agni or normal condition of Agni is responsible for strength, health, longevity and vital breath. Food substances undergo metabolic transformation by the effect of Jatharagni, Bhutagni and Dhatvagni. Jatharagni is the main principle substance responsible for disease and health. During its normalcy it is responsible for longevity, complexion, strength, health, enthusiasm, well built, lustre, immunity (Ojas). ${ }^{6}$ Jatharagni is the chief among all types of Agni's because functions of Bhutagni and Dhatvagni depend on this. Aggravation or diminution of Jatharagni results in aggravation or diminution of Bhutagni and Dhatvagni. Therefore by all means one has to protect Jatharagni by consuming suitable wholesome dietetics and behaviour because longevity and strength depends on normal state of Agni. ${ }^{7-10}$

\section{Types of agni}

Three main types of Agni have been described in Ayurveda namely Jatharagni / Pachakagni, Bhutagni and Dhatvagni. ${ }^{9}$ a. Status of jatharagni according to dosha: Different functional states of Jatharagni are produced due to influence of Doshas.

i. Mandagni: Due to influence of Kapha causing Amajirna.

ii. Tikshnagni: Due to influence of Pitta causing Vidagdhajirna.

iii. Vishamagni: Due to influence of Vata causing Vishtabdhajirna.

iv. Samagni: Equilibrium state of Dosha.

Except Samagni remaining three types of Agnis causes development of diseases. Vatika disorders arise from Vishamagni; Pittaja disorders arise from Tikshnagni and Kaphaja disorders arise from the mandagni ${ }^{1}$.

\section{Role of agni in the genesis of diseases}

Healthy state of body and diseased condition is entirely dependent on Agni. Simultaneous and continuous circulation of Rasadhatu takes place all over the body by the help of Vyana vata. If any abnormality evolved in the Rasavaha Srotas (channels carrying Rasa) as a result disease manifest like cloud in the sky brings rain. In the same way abnormality in Dosha manifest diseases. ${ }^{11,12}$ Dosha (body humors) get aggravated by the disturbed functions of Agni. That's why life span, health, strength and nourishment etc. are depends on Agni.

\section{Aetiology of ajirna}

If a person afflicted with

i. Atyambupana (Drinking large quantity of water)

ii. Vishmashana (Taking food either in large or small in quantity and at unusual times)

iii. Sandharana (Suppression of natural urges)

iv. Swapnaviparyaya (Loss of sleep at nights or sleeping during day)

v. Irshya (Envy)

vi. Bhaya (Panic)

vii. Krodha (Annoyance) 
viii. Lubdhane(Voracious)

ix. Rug dainya (Suffering from disease)

x. Pradeshayuktane cha sevyamanamannam (Taking food with jealousy), ${ }^{13}$ Chinta (Stress), Shoka (Grief) and Dukh (Sadness). ${ }^{14}$

\section{Samrapti or pathogenesis of Ajirna ${ }^{15}$}

Due to above aetiological factors Agni becomes greatly vitiated and fails to complete the process of digestion in sequence leading to formation of undigested food substances causes sourness and which becomes toxic in nature and initiates pathologic process inside the gastrointestinal tract and produces many diseases. Such patients do not digest the food even though consumed at proper time, quantity, wholesome diet and easily digestible food substances.

\section{Lakshana (symptoms) of ajirna}

The general signs and symptoms of Ajirna are abdominal distension, general malaise, headache, fainting, giddiness, stiffness in back and waist, yawing, body ache, fever, vomiting, tenesmus, anorexia and indigestion. ${ }^{16}$

\section{Types of ajirna}

According to predominance of vitiated doshas ajirna is broadly classified into three categories 3
i. Amajirna: Due to vitiation of Kapha dosha.
ii. Vidagdhajirna: Due to vitiation of Pitta dosha.
iii. Vishtabdhajirna: Due to vitiation of Vata dosha.
iv. Other types of Ajirna.
v. Rasasheshajirna- Related to Ahara Rasa indigestion on nutrient of food.

vi. Dinapaki-Ajirna - In which the food is digested on next day but causes no difficulty.

vii. Prativasara Ajirna- Which is found every day normally, immediately after taking food.

\section{Specific sign and symptoms of various types of ajirna}

a. Amajirna: Amajirna is characterised by heaviness of the abdomen or of the whole body, nausea, swelling of the cheeks and eyes, belching and similar to those occurring soon after meals signify occurrence of Amajirna. ${ }^{17}$

b. Vidagdhajirna: Vidagdhajirna is characterised by giddiness, thirst, fainting, sour and hot belching, excessive perspiration and burning sensation inside the body. ${ }^{17}$

c. Vishtabdhajirna: Vishtabdhajirna is characterised by pricking pain in the abdomen, long stasis, tympanitis, and non-movement of flatus, obstruction of stool, delusion and general malaise. ${ }^{17}$

d. Rasheshajirna: Rasheshajirna is characterised by aversion to food, pure belching and heaviness. ${ }^{17}$

\section{Complications}

If Ajirna is not managed properly leading to development of Fatal signs .i.e. fainting, delirium, vomiting, excessive salivation, debility, giddiness and death. ${ }^{18}$

\section{Discussion}

Food has been given a very significant place in individual's lives because it is primary requirement of body. It is a basic need being the source of mental and physical energy. The food that is eaten, not only effects body and the efficiency of mind but directly effects nature and habits also. ${ }^{19}$ The carbohydrates, starches and compound sugars are converted into glucose or dextrose when they are ready to be absorbed as a part of the blood. The fats are broken down into glycerine and fatty acids, in which forms they pass through specialized villi into the lymph. The circulatory system, made up of blood vessels and lymphatics, carries the absorbed food materials into the important stations that come next. The liver receives all the nutrients from the blood except the fats, which enter directly from the intestines into the lymph stream. As the absorbed nutrients enter the circulation, the liver plays a great role in further chemicalizing the protein and carbohydrate products. The colon or large intestine plays the next important role in the alimentation of foods. The residues which cannot be absorbed through the villi move on into the colon, where a certain amount of absorption of moisture takes place, leaving a variable solid or semi-solid faecal mass for excretion. ${ }^{20}$

\section{Atyambupana (drinking too much of water)}

Ayurveda also teaches the importance of maintaining a strong digestive fire. The easiest way to put out a fire is to pour water on it; therefore, the digestive fire will also be diminished when drinking too much water or beverage. There is no quicker way to upset proper digestion than to regularly introduce copious amounts of water into the stomach. The natural digestive enzyme secretions in the stomach and small intestine are affected in such a way so as to diminish their potency. That is because the proper digestion and assimilation of food is the single greatest determinant of health. Again, according to Ayurveda, the vast majority of medical conditions find their source in the creation of Ama. Ama is the "toxic by product generated due to improper or incomplete digestion." Drinking too much fluid with the meal is therefore never recommended. The long-term practice of drinking 8 glasses of water per day will inevitably create more Ama in the system for these reasons. If this waste product is not systematically removed by the body's primary detoxification pathways, various health conditions will eventually arise..$^{21}$

\section{Vishamashana( intake of food in inadequate quantity and improper time)}

One should not take food before or after the appropriate time or don't consume less or more quantity without considering the nature of food substances. Taking food before the digestion of the previous meal, the digestive product of previous meal that is immature Rasa gets mixed up with the products of food taken afterwards, brings the provocation of all the Doshas instantaneously and body may suffer from many disorders or diseases. On the other hand if food is taken after digestion of the previous meal, Doshas remain in their proper places and Agni is provoked, there is proper appetite, the entrances of the channels of circulation remain properly open, eructation is purified, unimpaired cardiac function, proper passing of flatus and proper manifestation of the urges for urine and stool, product of food does not vitiate the body elements and promotes longevity in its entirely. So food should be taken after digestion of previous meal. ${ }^{22}$ Taking food after time of hunger, digestive fire is disturbed by Vata, taken food is digested with difficulty and reduces loss of appetite. Food in deficient quantity produces discontent and reduces strength while that in excessive quantity causes lassitude, heaviness, gurgling 
sound and malaise. Proper digestion requires good food, proper eating habits, enough digestive enzymes and other favourable conditions in the intestines. Causes for putrefaction include eating too much protein at one time, insufficient chewing, bad food combinations, and deficiencies of digestive enzymes. ${ }^{23}$

\section{Sandharana (suppression of natural urges)}

Suppression of natural urges plays an important role in the causation of Ama. Most of the not following the dinacharya(daily regimen) and ritucharya(seasonal regimen)as described in Ayurvedic samhitas for the maintenance of health. One should excrete body waste from time to time to regain healthy status otherwise it causes many troubles and if is persist for longer duration leading to development of the diseases. Vegasandharana in the sense, Malavega Sandharana (i.e. holding the reflexes of defecation and micturition) viz. accumulation of Malas(waste products) for longer periods in its Sthanas causing Amavisha(toxic substance) as a result it brings abnormal reactions and favours development of diseases. Hurried lifestyles and not heeding attention to nature calls brings dishomeostasis inside the body. This ultimately leads to vitiation of Apanavata which vitiates Samanavata leading to vitiation of digestive power and this vitiated digestive power cannot digest even light diet also. Almost diseases manifest due to suppression of natural urges. Further inhibition of natural urges brings aggravation of Dosha, leads to vitiation of Agni i.e. Mandagni which favors the development of Ama. The role of vegasandharana in triggering the Doshas and its influence on Agni is well described by Acharya Charaka in Siddhi Sthana in relation to 'Sadaaturas' (always suffered from diseases) due to suppression of natural urges. ${ }^{24}$

\section{Irshya, bhaya, krodha, lubdhane, chinta, shoka, dukh and pradeshayuktane cha sevyamanamannam}

Digestive issues are a prominent part of living with anxiety. In fact, it can be so normal that many people don't even realize that anxiety is affecting the way they digest food. ${ }^{25}$ Stress tends to affect the normal functions of digestive system. The large intestine is particularly sensitive to stress, which tends to slow or even stop its activity and it is a major cause of constipation. ${ }^{26}$ Hydrochloric acid secretion may be completely inhibited by stress, emotion, or worry. It is the low-grade, long-term, emotionally oriented life stress is the main culprit. Intense stress is associated more with HCL over (hyper) secretion and peptic ulcer disease (at least initially). As the stress continues, the body is exhausted and HCL production is no longer adequate. ${ }^{27}$

The changes that affect digestion don't start in stomach. They actually start in brain. The human brain has a limited amount of resources. During anxiety there is an activation of the "fight or flight" response, which is designed to make it easier to escape danger. The fight or flight response takes up a lot of brain's resources, so to compensate it slows down parts of brain that aren't as necessary, such as the muscles involved in digestion28. The mechanism of inhibition with emotions would seem to be stimulation of the sympathetic nervous system on one hand and a reflex increase in the secretion of adrenaline have an inhibiting effects on gastric secretions leading to Mandagni condition. Neuroharmonal mechanism responsible for the secretion of digestive juices, enzymes, and regulation of general metabolism is under influence of psychological factors vice versa (Sharirika Manasika Paraspara Sambandha), hence Manasika mandyata reflects in Agnimandyata in turn on Amotpatti . Similarly, the same neurotransmitters in brain that are altered and affect mood, like serotonin, also play a role in sending signals to the gut. While low serotonin can cause anxiety, anxiety can also cause low serotonin, and that means that some of the messengers that are normally travelling into body are possibly being created at a lower rate, leading to digestion issues28. Another issue relates to adrenaline. During the fight or flight response, body creates massive amounts of adrenaline to give body extra energy. While adrenaline does this, body starts essentially processing nutrients at rates that aren't ideal. It changes how body processes nutrients as well and could conceivably affect digestive health. ${ }^{28}$

\section{Rug dainya (Suffering from disease)}

Having enough HCL (hydrochloric acid or stomach acid) is critical for good digestion and immune health. Without adequate HCL food is incompletely digested and failure of assimilation occurs. Impaired health may also reduce the production of many chemicals in the intestinal tract that protect it from invaders or bacteria that should not be there and are harmful. Chronic illness causes the less secretion of HCL resulting Ajirna. ${ }^{29}$

\section{Shayyaprajagare, Swapnaviparyaya ${ }^{30}$}

Digestion, absorbtion and assimilation of food are a process that requires a great deal of energy. Adequate rest associated with full sleep ensures that digestive organs have time for rest and repair. Lack of sleep also makes more susceptible to stresses, which can significantly influence digestive symptoms. Studies also have shown that many patients with irritable bowel syndrome and "sensitive stomach" experience increased symptoms the morning after a restless night.

\section{Treatment}

Management of Ajirna comprises of fasting and other purificatory and pacification measures should be considered to get relief from Ajirna.

i. Sweet \& fresh buttermilk with a pinch of cumin seed powder and Trikatu Churna should be taken after meals. ${ }^{31}$

ii. Ayurveda also recommends a very simple solution for people with digestive problems. Take some freshly grated ginger, sprinkle some rock salt on it and chew it just before beginning the meal. It will result in elimination of any kind of digestive problems, gas, belching etc. ${ }^{32}$

iii. Avoid drinking excessive water during hunger because it can weaken the digestive fire.

\section{Medicines}

\section{The following medicines are useful to treat Ajirna ${ }^{33}$}

i. Amairna - Hingvashtaka Churna, Lasunadi Vati, Sanjivani Vati, Chitrakadi vati.

ii. Vidagdhairna- Shankha Vati, Lavanabhaskara Churna, Arogyavardhni Vati.

iii. Rasaseshajirna- Lavana Bhaskar Churna, Agnitundi Vati, Sukti bhasma.

\section{Conclusion}

Deranged functions of Agni leads to indigestion of food are known as Ajirna (indigestion). Ajirna is the primary source of production of ama which is the cause of almost diseases. So, all the Acharyas have described Ajirna in detail including its aetiology, symptoms, 
fatal sign, and treatment also. Avoidance of the etiological factor is the preliminary step in any disease management. Improper life style, erratic seasonal regimen, mental disturbance and related to other diseases may contribute in the development of Ajirna.

\section{Acknowledgments}

None.

\section{Conflicts of interest}

Author declares there are no conflicts of interest.

\section{Funding}

None.

\section{References}

1. http://www.ayurvedalive.in/ajirna-indigestion

2. Yadunandan Upadhaya. Agnimandh Nidanam 6/14. Madhava Nidana Chaukambha Prakshan, Varanasi, India. 2013. pp. 230.

3. Yadunandan Upadhaya .Agnimandh Nidanam 6/5-6. Madhava Nidana Chaukambha Prakshan, Varanasi, India. 2013. pp. 227.

4. Saini Neera, Byadgi PS. Scientific Clinical evaluation of Ama in Amavata. MD. Thesis. Banaras Hindu University, Varanasi, India. 2013. p. 6-11

5. Byadgi PS. An insight into the understanding of agni and its clinical importance. IJAR0. 2011;2(6):1637-1641.

6. Ambika Dutt Shastri. Susruta Samhita, Aturopkraminiyadhaya 35/29. Chaukambha Sanskrit Sansthan, Varanasi, India. 2007.pp.134.

7. Byadgi PS. An insight into the understanding of agni and its clinical importance. IJAR. 2011;2(6):1637-1641.

8. Kasha Nath Shastri, Gorakh Nath Chuturvedi. Charak Samhita, Grahanichikitsadhaya 15/3-4. Chaukambha Bharat Academy, Varanasi, India . 2007.pp.453.

9. Byadgi PS. An insight into the understanding of agni and its clinical importance. IJAR. 2011;2(6):1637-1641.

10. Kasha Nath Shastri, Gorakh Nath Chuturvedi. Charak Samhita, Grahanichikitsadhaya 15/15. Chaukambha Bharat Academy, Varanasi, India. 2007.pp.455.

11. Kasha Nath Shastri, Gorakh Nath Chuturvedi .Charak Samhita, Grahanichikitsadhaya 15/16. Chaukambha Bharat Academy, Varanasi, India. 2007; pp.465.

12. Kasha Nath Shastri, Gorakh Nath Chuturvedi. Charak Samhita, Grahanichikitsadhaya 15/36-37. Chaukambha Bharat Academy, Varanasi, India. 2007.pp.458.
13. Ambika Dutt Shastri. Susruta Samhita, Annapanavidhiadhaya 46/507508. Chaukambha Sanskrit Sansthan, Varanasi, India. 2007.pp.223.

14. R.K.Sharma, Bhagwan Dash. Charak Samhita, Trividhkukshiya Vimaniyadhaya 2/9. Chaukambha Sanskrit Series Office, Varanasi, India. 2010;pp.135.

15. P.S. Byadgi. Ayurvediya Vikriti Vigyan and Roga Vigyan, Ajirna. Chaukambha Publication, Varanasi, India. 2009;p.74.

16. Kasha Nath Shastri, Gorakh Nath Chuturvedi. Charak Samhita, Grahanichikitsadhaya 15/45. Chaukambha Bharat Academy, Varanasi, India. 2007.pp.460.

17. Yadunandan Upadhaya. Agnimandh Nidanam 6/10-13. Madhava Nidana. Chaukambha Prakshan, Varanasi, India. 2013.pp.229.

18. Ambika Dutt Shastri. Susruta Samhita, Annapanavidhiadhaya 46/511. Chaukambha Sanskrit Sansthan, Varanasi, India. 2007;pp.223.

19. http://www.jainworld.com/preksha/vidyajain/pd11.htm

20. Byadgi PS . An insight into the understanding of agni and its clinical importance. IJAR. 2011;2(6):1637-1641.

21. http://naturalsociety.com/why-drinking-too-much-water-can-behazardous-to-your-health/\#ixzz3wGYyFjlO

22. Sharma Rk, Bhagwan Dash Charak Samhita, Rasavimaniyadhaya 1/24. Chaukambha Sanskrit Series Office, Varanasi, India. 2010.pp.129.

23. http://www.drlwilson.com/articles/DIGESTION

24. Saini Neera, Pal Pradeep Kumar, Byadgi PS. Role of Virrudh Chesta in the Development of Amavata. STM. 2015;4(1):52-54.

25. http://www.calmclinic.com/anxiety/symptoms/digestive-problems

26. http://www.drlwilson.com/articles/DIGESTION

27. Saini Neera, Pal Pradeep Kumar, Byadgi PS. Role of Virrudh Ahara in the Genesis of Amavata. AJPHR. 2015;3(3):1-10.

28. http://www.calmclinic.com/anxiety/symptoms/digestive-problems

29. http://branchbasics.com/ways-to-increase-stomach-acid-production/

30. http://livingwithgastroparesis.com/gastroparesis-sleep/\&Digestion

31. http://www.ayurvedalive.in/ajirna-indigestion

32. http://www.keralaayurveda.biz/content/good-eating-habits-ayurvedasays-can-aid-good-digestion

33. Krishna Gopal. Rasa Tantra Sara avum Siddhaproyaga Sangraha, Roganusar Ausaudh Suchi. 21 $1^{\text {st }}$ Krishna Gopal Ayurveda Bhawan, Kaleda, Ajmer, Rajasthan, India. 2012;2. 